\title{
BIOLOGICAL EFFECTS OF ECHINACEA PURPUREA ON HUMAN BLOOD CELLS
}

\author{
Gordana JOKSIĆ ${ }^{1}$, Sandra PETROVIĆ ${ }^{1}$, Ivana JOKSIĆ ${ }^{2}$, and Andreja LESKOVAC ${ }^{1}$ \\ Vinča Institute of Nuclear Sciences", Clinic of Gynecology and Obstetrics "Narodni Front", Belgrade, Serbia \\ Received in October 2008 \\ Accepted in March 2009
}

\begin{abstract}
The aim of this study was to investigate radioprotective properties of Echinacea purpurea tablets in vivo. We analysed lymphocyte chromosome aberrations (CA), micronuclei (MN), apoptosis of leukocytes and haematological parameters in a group of radiation workers who were identified as carrying dicentric chromosomes in their lymphocytes. All radiation workers were taking two $275 \mathrm{mg}$ Echinacea tablets b.i.d., according to a pharmacist's recommendation. All parameters were analysed before and after the two-week treatment. At the end of the treatment lymphocyte CA frequency dropped significantly, and the number of apoptotic cells increased. The inverse lymphocyte-to-granulocyte ratio at the beginning of the study changed to normal at its end. In conclusion, biological effects observed after administration of Echinacea purpurea preparation suggest that it may be beneficial for the prevention of adverse health effects in workers exposed to ionising radiation.
\end{abstract}

KEY WORDS: apoptosis, ionising radiation, micronuclei, protective effects

Low-dose ionising radiation may affect living cells in three ways: 1) injured or damaged cells repair themselves without residual damage; 2) cells die; or 3 ) cells misrepair themselves, which eventually lead to a structural and/or functional change.

Radiation-induced aberrations can be observed in human lymphocytes within a few hours from exposure; their frequency is related to the dose and type of radiation, and can be detected in blood samples taken long after the exposure (1). Chromosomal damage can indirectly be estimated by scoring micronuclei (MN) (2). The formation of $\mathrm{MN}$ in dividing cells is the result of unrepaired or misrepaired chromosomal breaks or chromosome malsegregation due to mitotic malfunction (3). Most MN studies have been using cultured peripheral lymphocytes, which lend themselves well to both genotoxicity testing and biomonitoring.

This study focused on chronic occupational exposure to ionising radiation. Earlier investigation has shown that $3 \%$ of radiologists occupationally exposed to ionising radiation carry dicentric chromosomes in their lymphocytes. Most of them showed a significantly decreased leukocyte ability to undergo apoptosis (4). Two factors blur the association between radiation exposure and clinical effects, that is, individual variability (due to genetic and environmental factors) and the presence of various defensive mechanisms which counteract to oxidative stress induced by irradiation (5). Current biomonitoring mostly uses cytogenetic markers of chromosomal aberrations and micronuclei in circulating lymphocytes. These biomarkers may be useful to identify individuals more vulnerable to radiation damage, and who might be eligible for preventive measures such as limiting the exposure and pharmacological or dietary radioprotection.

The aim of this study was to evaluate the radioprotective properties of Echinacea purpurea extracts in vivo. For this purpose, radiology technicians, who were identified as carrying dicentrics in their lymphocytes were asked to take Echinacea purpurea 
tablets and were analysed for chromosome aberrations, micronuclei, apoptosis, and haematological parameters before and after the treatment.

\section{MATERIALS AND METHODS}

\section{Study design}

The exposed group included 10 radiology technicians identified as carrying dicentric chromosomes in their lymphocytes during routine checkups. Lymphocyte aberrations in these subjects were accompanied by mild leucopoenia and imbalance in the ratio between lymphocytes, monocytes, and granulocytes. Ten subjects, all men, were willing to take two Echinacea purpurea tablets (Ehinacea ${ }^{\circledR}$, Strong Nature, Serbia) twice a day (b.i.d.) for two weeks. Each $275 \mathrm{mg}$ tablet contains Echinacea purpurea dry extract standardised at $8.3 \%$ of total phenolic content (calculated in terms of chlorogenic acid units). Echinacea preparation contains caffeic acid derivatives, sugar, and caffeic acid esters - echinacosides. Throughout the treatment, the 10 subject took no other drugs/preparations or vitamin supplements.

The average group age was $(38.7 \pm 3.4)$ years, and average occupational exposure duration $(14.6 \pm 3.4)$ years. The radiation doses measured by thermoluminescent dosimeters (TLD) on the chest were below the annual limit of $20 \mathrm{mSv}$ (Table 1). Lymphocyte micronuclei, chromosomal aberrations, and apoptosis were analyzed at the beginning and at the end of treatment. This study used each subject as his own control.

\section{Blood sampling}

Peripheral blood samples were collected in heparinised vacutainers by venipuncture in accordance with the Declaration of Helsinki and current health ethics regulations in Serbia $(6,7)$. Venous blood was collected in a test tube containing an anticoagulant (ethylenediaminetetraacetic acid, EDTA) to prevent clotting.

\section{Blood count}

The blood was mixed well (but not shaken) and inserted into the haematology analyzer CELL-DYN 3700 (Abbott Laboratories, Illinois, USA) that recorded haemoglobin concentration, red blood cell (RBC), white blood cell (WBC), neutrophil (NpG), lymphocyte (Ly), and monocyte (Mo) counts.

\section{Chromosomal aberration analysis}

For scoring chromosomal aberrations, standard methods (1) were used: aliquots of heparinised whole blood $(0.5 \mathrm{~mL})$ were set up in cultures containing PBmax-karyotyping medium (Invitrogen-Gibco, Paisley, UK). Cells were harvested $48 \mathrm{~h}$ after initiation of culture. For the last three hours the cells were cultured in the presence of colchicine (Sigma Aldrich, St. Louis, MO. USA) in the final concentration of $2.5 \mu \mathrm{g} \mathrm{mL}^{-1}$. Slides were prepared according to the standard protocol for chromosomal aberration analysis. After staining, 200 well-spread and complete first-division metaphases per subject were analysed for unstable chromosome-type aberrations, i.e. dicentric and rings chromosomes, and acentric fragments. The scoring criteria were based on the IAEA recommendations (1).

\section{Micronucleus test}

For the micronucleus test, aliquots of heparinised whole blood $(0.5 \mathrm{~mL})$ were set up in cultures

Table 1 General characteristics of the ten radiology technicians exposed to $<20 \mathrm{mSv}$ of irradiation a year

\begin{tabular}{lccc}
\hline Subject No. & Age / year & $\begin{array}{c}\text { Occupational exposure / } \\
\text { year }\end{array}$ & Smoking \\
\hline 1 & 37 & 14 & - \\
2 & 43 & 19 & + \\
3 & 39 & 16 & - \\
4 & 36 & 13 & + \\
5 & 41 & 16 & + \\
6 & 34 & 11 & + \\
7 & 36 & 11 & + \\
8 & 38 & 13 & + \\
9 & 45 & 21 & - \\
\hline mean \pm S.D. & 38 & 12 & \\
\hline
\end{tabular}


containing PBmax-karyotyping medium (InvitrogenGibco). The slides were prepared according to the method described by Fenech (8). At least 1000 binucleated cells were scored per culture. Cytokinesisblock proliferation index (CBPI) was calculated using the following equation:

$$
\mathrm{CBPI}=[\mathrm{MI}+2 \mathrm{MII}+3(\mathrm{MIII}+\mathrm{MIV})] / \mathrm{N} \text {, }
$$

where MI-MIV is the number of cells with one to four nuclei, respectively, and $\mathrm{N}$ is the number of cells scored (9).

\section{Apoptosis of leukocytes}

For the apoptosis assay, blood aliquots of $0.5 \mathrm{~mL}$ from each subject were incubated with the RPMI-1640 medium (Invitrogen-Gibco) supplemented with $15 \%$ calf serum without phytohaemagglutininin in a $\mathrm{CO}_{2}$ incubator for $24 \mathrm{~h}$. After incubation, cells were gently washed with saline $(0.9 \% \mathrm{NaCl})$ at $37^{\circ} \mathrm{C}$ and fixed in methanol:acetic acid (3:1). The pellet was then fixed in $96 \%$ ethanol. Apoptosis was assessed by flow cytometric identification of cells displaying apoptosisassociated DNA condensation. Three parameters were
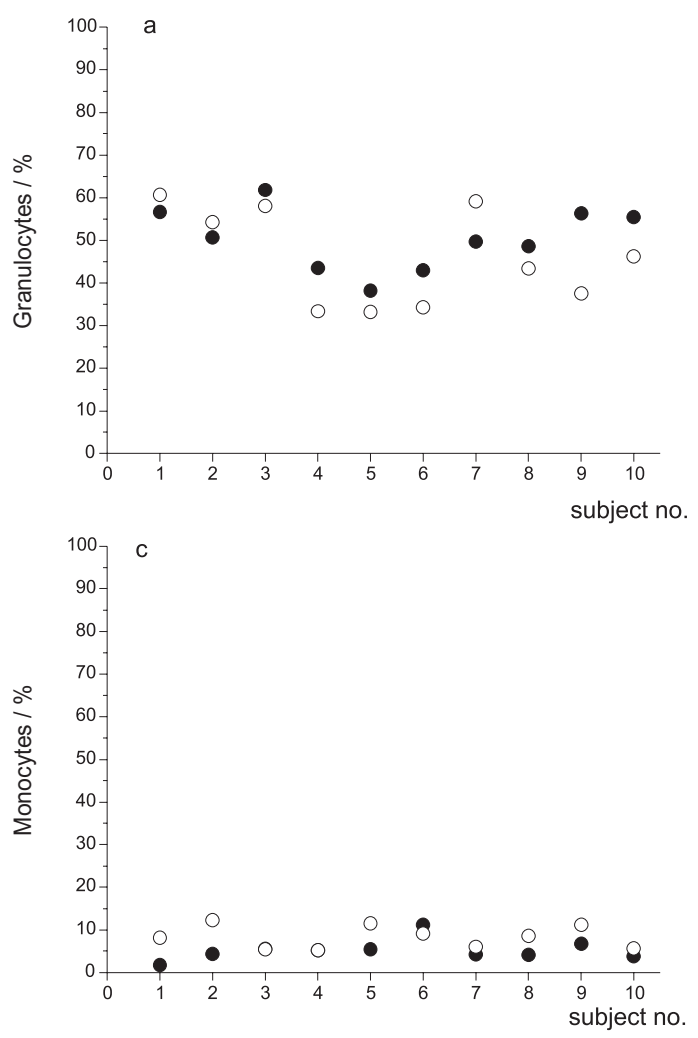

measured: cell size, granularity, and DNA content. DNA content was assessed by measuring the UV fluorescence of propidium iodide-stained DNA. Cytotoxicity was defined as the population of cells with reduced DNA fluorescence (10). Each analysis included 10000 events per sample.

\section{Statistics}

Statistical analysis of each parameter was carried out using the statistical software package Statistica version 5.5 for Windows. It included the frequency of chromosomal aberrations and micronuclei in binucleated cells, leukocyte count, and absolute lymphocyte, granulocyte (neutrophil), and monocyte counts. The results were evaluated using the Spearman rank order correlation and Wilcoxon matched-paired test.

\section{RESULTS}

Table 2 and Figure 1a-c show individual data on haemoglobin concentration, red blood cell
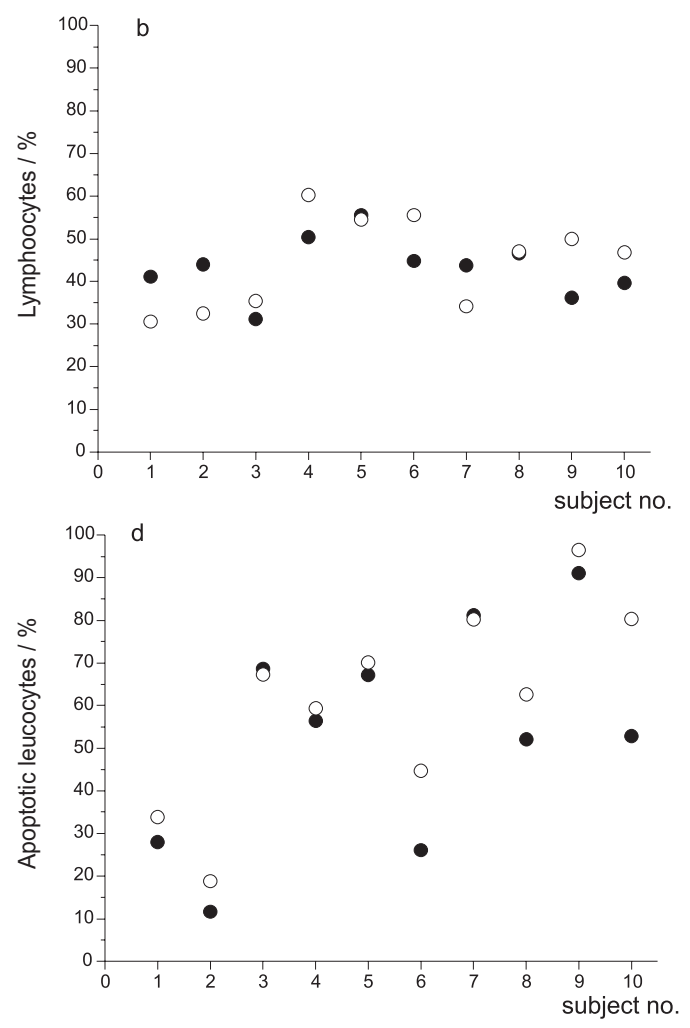

Figure 1 Percentage of granulocytes (a), lymphocytes (b), monocytes (c), and apoptotic leukocytes (d) in radiology technicians before (open circle) and after a two-week treatment with Echinacea purpurea preparation (closed circle). 
(RBC), white blood cell (WBC), neutrophil (NpG), lymphocyte (Ly), and monocyte (Mo) counts in radiology technicians.

Apoptosis is expressed as the percentage of cells displaying apoptotic granularity (Figure 1d). The sum of exchange aberrations, lymphocyte micronuclei, and proliferation index are shown on Table 3.

At the beginning of treatment, the leukocyte count positively correlated with the incidence of chromosomal aberrations and negatively with

Table 2 Blood count including haemoglobine ( $H b), R B C, W B C$, neutrophil (NpG), lymphocyte(Ly), and monocyte (Mo) count in radiation workers at the beginning (*) and after two weeks of treatment with Echinacea purpurea preparation $(* *)$

\begin{tabular}{|c|c|c|c|c|c|c|c|c|c|c|c|c|}
\hline \multirow{2}{*}{$\begin{array}{l}\text { Subject } \\
\text { No. }\end{array}$} & \multicolumn{2}{|c|}{$\mathbf{H b} / \mathbf{g ~ L}^{-1}$} & \multicolumn{2}{|c|}{$\mathrm{RBC} / \mathrm{x} 10^{12} \mathrm{~L}^{-1}$} & \multicolumn{2}{|c|}{$\begin{array}{c}\text { Total WBC / } \\
x 10^{9} \mathrm{~L}^{-1}\end{array}$} & \multicolumn{2}{|c|}{ NpG } & \multicolumn{2}{|c|}{ Ly } & \multicolumn{2}{|c|}{ Mo } \\
\hline & * & $* *$ & * & $* *$ & * & $* *$ & $*$ & $* *$ & * & $* *$ & $*$ & $* *$ \\
\hline 1 & 140 & 144 & 5.05 & 5.24 & 8.66 & 6.74 & 4.91 & 4.09 & 3.56 & 2.06 & 0.16 & 0.55 \\
\hline 2 & 138 & 139 & 5.27 & 5.23 & 8.17 & 7.70 & 4.14 & 4.18 & 3.60 & 2.50 & 0.36 & 0.95 \\
\hline 3 & 167 & 162 & 4.98 & 4.81 & 7.68 & 6.80 & 4.75 & 3.95 & 2.39 & 2.41 & 0.43 & 0.37 \\
\hline 4 & 152 & 160 & 5.21 & 5.11 & 9.33 & 9.44 & 4.06 & 3.15 & 4.70 & 5.69 & 0.49 & 0.50 \\
\hline 5 & 151 & 153 & 4.76 & 4.62 & 5.11 & 5.54 & 1.95 & 1.84 & 2.84 & 3.02 & 0.28 & 0.64 \\
\hline 6 & 146 & 153 & 4.29 & 4.37 & 8.73 & 8.51 & 3.75 & 2.92 & 3.91 & 4.73 & 0.98 & 0.78 \\
\hline 7 & 139 & 136 & 4.91 & 4.86 & 3.54 & 5.65 & 1.76 & 3.34 & 1.55 & 1.93 & 0.15 & 0.34 \\
\hline 8 & 161 & 158 & 5.62 & 5.48 & 8.67 & 8.30 & 4.21 & 3.61 & 4.04 & 3.90 & 0.36 & 0.72 \\
\hline 9 & 164 & 172 & 5.70 & 5.99 & 5.95 & 4.90 & 3.35 & 1.84 & 2.15 & 2.45 & 0.40 & 0.55 \\
\hline 10 & 159 & 164 & 5.12 & 5.26 & 8.22 & 8.33 & 4.56 & 3.85 & 3.26 & 3.90 & 0.31 & 0.48 \\
\hline Mean & 151.70 & 154.10 & 5.09 & 5.10 & 7.41 & 7.19 & 3.74 & 3.28 & 3.20 & 3.26 & 0.39 & 0.59 \\
\hline \pm S.D. & \pm 10.77 & \pm 11.50 & \pm 0.41 & \pm 0.46 & \pm 1.89 & \pm 1.50 & \pm 1.10 & \pm 0.86 & \pm 0.96 & \pm 1.25 & \pm 0.23 & \pm 0.19 \\
\hline
\end{tabular}

Table 3 Incidence of chromosome breaks, incidence of micronuclei, and proliferation index in radiation workers at the beginning and after two weeks of treatment with Echinacea purpurea preparation.

\begin{tabular}{|c|c|c|c|c|c|c|c|c|c|}
\hline \multirow{2}{*}{$\begin{array}{l}\text { Subject } \\
\text { No. }\end{array}$} & & \multirow{2}{*}{$\begin{array}{l}\text { Incidence of } \\
\text { chromosome } \\
\text { breakage } \\
\text { per cell* }\end{array}$} & \multirow{2}{*}{$\begin{array}{c}\text { Incidence } \\
\text { of MN per } \\
1000 \mathrm{BN} \\
\text { cells }\end{array}$} & \multicolumn{4}{|c|}{$\begin{array}{l}\text { Micronuclei distribution } \\
\text { Number of cells with: }\end{array}$} & \multirow{2}{*}{$\begin{array}{l}\mathrm{mBN} \\
\text { cells }\end{array}$} & \multirow{2}{*}{ CBPI } \\
\hline & & & & $\begin{array}{c}0 \\
\text { MN }\end{array}$ & $\begin{array}{c}1 \\
\text { MN }\end{array}$ & $\begin{array}{c}2 \\
\mathrm{MN} \\
\end{array}$ & $\begin{array}{c}3 \\
\mathbf{M N} \\
\end{array}$ & & \\
\hline 1 & & 0.035 & 38 & 1153 & 36 & 3 & 1 & 3 & 1.94 \\
\hline 2 & & 0.035 & 40 & 1036 & 27 & 5 & 2 & 3 & 1.96 \\
\hline 3 & & 0.030 & 33 & 1050 & 24 & 6 & 0 & 3 & 1.97 \\
\hline 4 & at the & 0.025 & 37 & 1164 & 39 & 3 & 0 & 3 & 1.93 \\
\hline 5 & beginning & 0.025 & 24 & 1552 & 22 & 8 & 0 & 2 & 1.98 \\
\hline 6 & of & 0.025 & 32 & 1006 & 25 & 4 & 0 & 3 & 1.98 \\
\hline 7 & treatment & 0.015 & 44 & 1058 & 34 & 4 & 2 & 4 & 1.97 \\
\hline 8 & & 0.015 & 25 & 1161 & 18 & 6 & 0 & 2 & 1.97 \\
\hline 9 & & 0.015 & 24 & 1193 & 27 & 1 & 0 & 2 & 1.93 \\
\hline 10 & & 0.010 & 16 & 1245 & 20 & 0 & 0 & 2 & 1.99 \\
\hline 1 & & 0.015 & 37 & 1191 & 30 & 5 & 2 & 3 & 1.95 \\
\hline 2 & & 0.020 & 37 & 1164 & 31 & 4 & 2 & 3 & 1.97 \\
\hline 3 & & 0.010 & 27 & 1209 & 33 & 0 & 0 & 3 & 1.98 \\
\hline 4 & & 0.000 & 12 & 1374 & 16 & 0 & 0 & 1 & 1.94 \\
\hline 5 & atter two & 0.025 & 21 & 1185 & 25 & 0 & 0 & 2 & 1.97 \\
\hline 6 & $\begin{array}{l}\text { Weeks or } \\
\text { treatment }\end{array}$ & 0.000 & 29 & 1056 & 32 & 0 & 0 & 3 & 1.99 \\
\hline 7 & treatment & 0.005 & 18 & 1146 & 9 & 6 & 0 & 1 & 1.97 \\
\hline 8 & & 0.000 & 11 & 1432 & 16 & 0 & 0 & 1 & 1.98 \\
\hline 9 & & 0.000 & 7 & 1314 & 9 & 0 & 0 & 1 & 1.94 \\
\hline 10 & & 0.005 & 34 & 1251 & 35 & 3 & 1 & 3 & 1.97 \\
\hline
\end{tabular}

*dicentrics or rings, acentrics and chromosome breaks $m B N$ - binucleated cells with $M N$

CBPI - cytokinesis-block proliferation index 
micronuclei and apoptosis, but not at a statistically significant level.

At the end of the treatment, a statistically significant correlation was found between the absolute granulocyte count and micronuclei $(\mathrm{R}=0.68, \mathrm{P}<0.05)$. An inverse correlation at the border of significance was found between the monocyte count and the percentage apoptotic leukocytes $(\mathrm{R}=-0.59, \mathrm{P}<0.06)$.

Wilcoxon matched-pairs test showed statistically significant differences in micronucleus frequency and apoptotic cells between the beginning and the end of the treatment $(\mathrm{Z}=1.99, \mathrm{P}<0.05$ and $\mathrm{Z}=2.49, \mathrm{P}<0.02$, respectively). We also found a statistically significant difference between the percentage of monocytes at the beginning and at the end of the treatment $(\mathrm{Z}=2.09$, $\mathrm{P}<0.04)$.

\section{DISCUSSION}

Echinacea tablets have been marketed in Serbia as a herbal remedy. Previous studies with Echinacea preparations suggest that these products, possess antioxidative properties thanks to high phenolic content $(11,12)$. We based our dosage on earlier studies which used Echinacea at relatively low doses, lower than those used by many practicing herbalists (12).

Our group of ten volunteers was rather homogenous in age and occupational exposure duration. All were radiology department technicians of the City Clinical Hospital applying diagnostic procedures. During the last five years none exceeded the annual limit of $20 \mathrm{mSv}$. Six smoked, while the rest did not (see Table 1). The highest frequency of chromosomal aberrations was found in two nonsmokers and in one smoker. After the two-week treatment, tests have shown a significantly reduced frequency of chromosomal aberrations and micronuclei in nine of the 10 subjects, whereas leukocyte count decreased, but remained normal. The absolute granulocyte count dropped and monocyte count increased. The percentage of apoptotic cells also increased; it was $53.5 \%(\mathrm{SD}=25.26)$ before and $61.36 \%(\mathrm{SD}=23.36)$ after the treatment.

Furthermore, the two-week treatment with Echinacea purpurea restored a balance between haematological parameters. Echinacea owes its powerful radioprotective effects to the scavenging capacity of phenolic compounds caffeic acid, cichoric acid, and echinacoside. Earlier findings of the beneficial effects of natural phenolic compounds have shown that they possess stronger antioxidant capacity than vitamins (13). The radioprotective properties of medicinal plants such as Podophyllum hexandrum, Ocimum sanctum, Ginko biloba, and Mentha piperita have been attributed to the presence of polyphenols capable to stop propagation steps of lipid peroxidation and chelate transitional metal ions, and hence to inhibit free radical formation (14).

Biologically active compounds of Echinacea reduce the yield of radiation-induced micronuclei, mainly by stimulating apoptosis, which is a radiorecovery effect. This effect is important, particularly for long-lived chromosomal aberrations, which could lead to the overexpression of oncogenes and to cancer development. Echinacea enhances apoptosis of irradiated cells as a physiological mechanism with no inflammation, which looks promising for helping recovery after irradiation.

Adverse health effects of ionising radiation are still closely investigated. Radiation can activate oncogenes through a number of mechanisms including point mutation, chromosomal rearrangement, or chromosomal translocations. If irradiation results in the loss of a tumour suppressor gene, then it may become conducive to the expression of a malignant phenotype. Chromosomal aberrations in peripheral lymphocytes were found to be an intermediate endpoint in carcinogenesis $(15,16)$. The study of Bonassi et al. (17) has also shown that a higher micronucleus frequency may also be related to overall genetic instability and is predictive of cancer proneness. Low doses of ionising radiation induce oxidative stress which can significantly modulate some transcription factors. Once activated, these transcription factors might drive transcription of survival-related proteins. For instance, ionising radiation modulates more than 100 genes in human endothelial cells, causing up-regulation of genes involved in coagulation and peroxidase activity (18). It also triggers signals that mobilise innate and adaptive immune systems to deal with the intrusion and repair tissue. Little is known about the role of signals in tissue responses to this agent. This signal could mediate the pathogenesis of or recovery from radiation damage and alter intrinsic cellular radiosensitivity (19). A number of healthy individuals (10\% to $15 \%)$ exhibit reduced $(65 \%$ to $80 \%$ of normal) repair capacity phenotypes (20). These damage-specific phenotypes are heritable traits associated with increased radiosensitivity. It is estimated that every individual will be a variant for 6 to 8 genes in both base excision repair and 
double-strand break repair pathways, whose primary responsibility is to repair DNA damage induced by ionising radiation (21). One of the most important recently studied genes is the Nijmegen breakage syndrome (NBS1) gene. While NBS is a rare disease, it is estimated that a significant proportion of the population may be heterozygous at this locus and be sensitive to radiation, even though they belong to "normal" population. NBS heterozygous individuals may be particularly susceptible to environmental, diagnostic, or therapeutic exposure to ionising radiation. Furthermore, heterozygous individuals may run an increased risk from ionising radiation at doses that are below the current workplace exposure limits.

Biologically active compounds from the Echinacea species are reported to possess immunomodulatory properties such as enhancement of monocytemacrophage activity (22). In our study, monocyte count and apoptotic ability of leukocytes clearly increased, which is attributed to the Echinacea treatment.

Further investigation of common polymorphisms at relevant genes in humans would single out reagents for cellular biology experiments and molecular epidemiological studies employing a genotype-tophenotype/health consequence paradigm and refine risk estimates associated with exposure to low-level ionising radiation. Understanding radiation effects in terms of coordinated multicellular responses that affect cellular fate may necessitate re-evaluation of radiation dose and risk concepts and provide avenues for intervention.

\section{CONCLUSION}

Administration of Echinacea purpurea preparation significantly reduces the incidence of radiationinduced chromosomal aberrations and micronuclei in human lymphocytes of radiation workers. Its powerful radioprotective capacities are achieved through free radical scavenging performed by polyphenols, which stimulate apoptosis and enhance monocyte-macrophage activity. Echinacea purpurea posseses remarkable protective properties and its biological activity could be important for many other diseases where lipid peroxidation products have been reported.

\section{Acknowledgement}

This study was supported by the Ministry of Science and Environmental Protection of Serbia (grant No. 143046).

\section{REFERENCES}

1. International Atomic Energy Agency (IAEA). Cytogenetic analysis for radiation dose assessment. Technical Report Series No. 405. Vienna: IAEA; 2001.

2. Ralmaho A, Sunjevaric I, Natarajan AT. Use of frequencies of micronuclei as quantitative indicators of X-ray induced chromosome aberrations in human peripheral blood lymphocytes: comparison of two methods. Mutat Res 1988;207:141-6.

3. Fenech M. Chromosomal biomarkers of genomic instability relevant to cancer. Drug Discov Today 2002;22:1128-37.

4. Joksic G, Petrovic S. Lack of adaptive response of human lymphocytes exposed in vivo to low doses of ionizing radiation. J Environ Pathol Toxicol Oncol 2004;3:195-206.

5. Miura Y. Oxidative stress, radiation-adaptive responses, and aging. J Radiat Res 2004;45:357-72.

6. Law on health care. Official Gazette of the Republic of Serbia, Parliament of the Republic of Serbia. 2005;107:112-61.

7. The World Medical Association (WMA). World Medical Association Declaration of Helsinki: Ethical principles for medical research involving human subjects [displayed 16 March 2009]. Available at http://www.wma.net/e/policy/ b3.htm.

8. Fenech M. The cytokinesis-block micronucleus technique: a detailed description of the method and its application to genotoxicity studies in human populations. Mutat Res 1993;285:35-44.

9. Surrales J, Xamena N, Creus A, Marco R. The suitability of the micronucleus assay in human lymphocytes as a new biomarker of excision repair. Mutat Res 1995;342:43-59.

10. Zamai L, Falcieri E, Zauli G, Cataldi A, Vitale M. Optimal detection of apoptosis by flow cytometry depends on cell morphology. Cytometry 1993;14:891-7.

11. Jurcic K, Melchart D, Holzmann M, Martin Pl, Bauer R, Doenecke A, Wagner H. Zwei Probandenstudien zur Stimulierung der Granulozyten-Phagozytose durch Echinacea-extrakt-haltige präparate. [Two clinical studies on the stimulation of granulocyte phagocytosis by preparations containing Echinacea, in German]. Z Phytother 1989;10:6770.

12. Barrett B. Medicinal properties of Echinacea: a critical review. Phytomedicine 2003;10:66-86.

13. Arora R, Gupta D, Chawla R, Sagar R, Sharma AK, Prasad J, Singh S, Samanta N, Sharma RK. Radioprotection by plant products: present status and future prospects. Phytother Res 2005;9:1-22.

14. Jagetia GC, Aruna R. The herbal preparation abana protects against the radiation-induced micronuclei in mouse bonemarrow. Mutat Res 1997;391:157-63.

15. Howe GR, Zablotska LB, Fix JJ, Egel J, Buchanan J. Analysis of the mortality experience amongst U.S. nuclear power industry workers following chronic low-dose exposure to ionizing radiation. Radiat Res 2004;162:517-26. 
16. Hagmar L, Brogger A, Hansteen IL, Heim S, Hogstedt B, Knudsen L, Lambert B, Linnainmaa K, Mitelman F, Nordenson I, Reuterwall C, Salomaa S, Skerfving S, Sorsa M. Cancer risk in humans predicted by increased levels of chromosomal aberrations in lymphocytes: Nordic study group on the health effects of chromosome damage. Cancer Res 1994;54:2919-22.

17. Bonassi S, Znaor A, Norppa H, Hagmar L. Chromosomal aberrations and risk of cancer in humans: an epidemiologic perspective. Cytogenet Genome Res 2004;104:376-82.

18. Bonassi S, Znaor A, Ceppi M, Lando C, Chang WP, Holland N, Kirsch-Volders M, Zeiger E, Ban S, Barale R, Bigatti MP, Bolognesi C, Cebuleska-Wasilewska A, Fabianova E, Fucic A, Hagmar L, Joksic G, Martelli A, Migliore L, Mirkova E, Scarfi MR, Zijno A, Norppa H, Fenech M. An increased micronucleus frequency in peripheral blood lymphocytes predicts the risk of cancer in humans. Carcinogenesis 2007;28:625-31.

19. Lanza V, Pretazzoli V, Olivieri G, Pasccarella G, Panconesi A, Negri R. Transcriptional response of human umbilical vein endothelial cells to low doses of ionizing radiation. J Radiat Res 2005;46:265-76.

20. Mohrenweiser HW, Jones IM, Wilson III, D. DNA repair gene variants: Understanding mechanisms of cellular response and estimating individual health risk from low-dose radiation. In: DOE Low Dose Radiation Research Program, Workshop I; 10-12 Nov 1999. Washington, D.C. Abstracts. [displayed 16 March 2009]. Available at http://lowdose. tricity.wsu.edu/99meeting/abstracts/mohrenweiser.html.

21. Bose M, Smith LE, Petrini J, Concannon P, Morgan WF. Genetic factors affecting susceptibility to low-dose radiation. In: Joint DOE/NASA Radiation Investigator's Workshop; 27-30 June 2001. Arlington, Virginia. Abstracts [displayed 16 March 2009]. Available at http://lowdose.tricity.wsu. edu/2001 mtg/abstracts/smith.htm.

22. Rininger JA, Kickner S, Chigurupati P, McLean A, Franck Z. Immunopharmacological activity of Echinacea preparations following simulated digestion on murine macrophages and human peripheral blood mononuclear cells. J Leukoc Biol 2000;68:503-10. 
Sažetak

\section{BIOLOŠKI UČINCI ECHINACEA PURPUREA NA KRVNE STANICE LJUDI}

Cilj ovog rada je utvrđivanje radioprotektivnih svojstava Echinacea purpurea ("Ehinacea", Strong Nature, Srbija) in vivo. Analizirani su kromosomske aberacije, mikronukleusi, apoptoza leukocita i hematološki parametri u skupini ispitanika profesionalno izloženih ionizirajućem zračenju u čijim je limfocitima utvrđena prisutnost dicentričnih kromosoma. Sve osobe profesionalno izložene ionizirajućem zračenju su uzimale 4 "Echinacea" tablete na dan, prema preporučenoj ljekarničkoj dozi. Svi parametri su analizirani na početku i nakon dva tjedna tretmana. Na kraju studije učestalost kromosomskih aberacija u limfocitima značajno je smanjena, dok je apoptotski potencijal leukocita povećan. Omjer limfocita i granulocita utvrđen na početku studije nakon dva tjedna je dostigao normalne vrijednosti. Uočena svojstva Echinacea purpurea mogu biti važna u prevenciji i ublažavanju učinaka štetnih za zdravlje.

KLJUČNE RIJEČI: apoptoza, in vivo, ionizirajuće zračenje, mikronukleusi, protektivni učinci

\section{CORRESPONDING AUTHOR:}

Gordana Joksić

Vinča Institute of Nuclear Sciences

POB 522, 11001 Belgrade, Serbia

E-mail:gjoksic@vinca.rs 